\title{
DEPOSITION AND COVERAGE OF SOYBEAN LEAF SURFACES BY SPRAYS APPLIED USING DIFFERENT ASSISTED BOOM SPRAYER SYSTEMS
}

\author{
Laercio L. Hoffmann ${ }^{1 *}$, Rafael Roehrig ${ }^{2}$, Walter Boller ${ }^{2}$, Carlos A. Forcelini
}

${ }^{1 *}$ Corresponding author. Universidade de Passo Fundo/ Passo Fundo - RS, Brasil.

E-mail: laercio.hoffmann@syngenta.com | ORCID: https://orcid.org/0000-0001-5056-0477

\section{KEYWORDS}

Application technology, Dropleg $^{\circledR}$, Vortex $^{\circledR}$

\begin{abstract}
Maintaining homogeneity in the distribution of fungicidal sprays applied throughout the plant, minimizing the variation between the upper and lower third of the plant, is one of the main challenges for application technologies with regard to soybean crops. To increase the deposition and leaf coverage of sprayed compounds, especially in the middle and lower thirds of the plant, we developed and tested alternative assisted boom sprayer systems. In this study, three assisted boom sprayer systems (Vortex ${ }^{\circledR}$, Dropleg ${ }^{\circledR}$, and chain curtain) were evaluated, in addition to the conventional system, in terms of the deposition and coverage of the leaf surface they achieved in the upper, middle, and lower thirds of plants using the fluorescent tracer Helios SC $500^{\mathrm{TM}}$. The assisted boom sprayer systems allowed the sprayed mixture to be better distributed throughout the plant. With the conventional spray system (without assitance), the deposition in the upper third was approximately 26 times higher than that in the lower third, whereas with the use of the assisted boom sprayer systems, the difference in deposition between these thirds was 11 times higher. Among the evaluated systems, the Dropleg ${ }^{\circledR}$ system presented the lowest depositional variation, which was only 5.5 times higher in the upper than in the lower third, because of the increased deposition achieved in the lower third of the plant. Leaf coverage varied from $41 \%$ to $81 \%$ in the upper third, from $24 \%$ to $43 \%$ in the middle third, and from $4 \%$ to $13 \%$ in the lower third of the plant. Using the conventional spray system, the leaf surface coverage was approximately 13 times higher in the upper third than in the lower third of the plant, whereas with the use of the assisted boom sprayer systems, especially the Dropleg ${ }^{\circledR}$ system, this variation was reduced by $73 \%$, and the coverage of the upper and lower thirds only differed by 3.5 times. Indeed, the Dropleg ${ }^{\circledR}$ system reached a leaf coverage of close to $13 \%$ in the lower third of the plant. The use of assisted boom sprayer systems improved the distribution of the mixture applied throughout the plant, reducing the differences among the thirds of the plant both in the levels of deposition and coverage of the leaf surfaces. The Dropleg ${ }^{\circledR}$ system increased the deposition and leaf coverage in the lower third of the plant the most, facilitating better distribution of the mixture.
\end{abstract}

\section{INTRODUCTION}

Many factors can depreciate the productivity of soybean crops, including pests and diseases, which means that management actions are needed, including the use of pesticides. To provide adequate levels of control, two variables are the most important in the application of pesticides: deposition levels and leaf surface coverage. Application deposition is related to the amount of the active ingredient present in each organ, portion, or stratum of the plant, and this is associated with the percent coverage of the plant or its organs, such as the leaves, achieved by the application, since many agrochemicals have low or no mobility in plant tissues.

In general, conventional spray techniques using hydraulic or centrifugal nozzles, regardless of the application volume, provide low deposition and coverage in the middle and lower thirds of the plant, especially in plants with high leaf areas like soybean, causing the applied products to have low efficiency (Prado et al., 2015;

\footnotetext{
${ }^{2}$ Universidade de Passo Fundo/ Passo Fundo - RS, Brasil. 
Graziano et al., 2017; Roehrig et al., 2018; Müller et al., 2018). This has negative impacts on pest and disease management, as the evolution or development of these problems proceeds from the lower portion of the plant towards the apex, between which the variations in the coverage of the leaf surface by applied pesticides can be as high as twenty-three times (Roehrig et al., 2018).

When evaluating the penetration of applied pesticide droplets into the soybean canopy using spray nozzles with differing spectra of droplets (fine, medium, and thick), Wolf \& Daggupati (2009) observed that the leaf coverage in the lower third of the plant did not exceed $10 \%$, since the leaf density was the factor that most strongly influenced the penetration of the droplets. In a study conducted by Debortoli et al. (2012), it was observed that, regardless of the applied droplets spectrum, only the upper third of the plant showed sufficient deposition of the active ingredient for the adequate protection of the leaves. Therefore, as the plants grow, the concentration of the droplets increases at the top of the canopy relative to that at the lower and middle parts of the plant.

Because of the variations in deposition and leaf coverage of the applied chemicals in sprays between plant parts, strategies to improve (i.e. reduce) these variations need to be developed, especially for the lower third of the plant (Cunha et al., 2014). In this sense, the use of airassisted boom sprayer systems, such as Vortex ${ }^{\circledR}$, Dropleg ${ }^{\circledR}$, and curtain of chains, could provide an effective alternative to conventional application methods.

The Vortex ${ }^{\circledR}$ air-assisted system consists of a turbine driven by a hydraulic motor with variable rotation, located in the center of the boom, which produces a volume of air that is distributed in the boom by an inflated duct and is released towards the canopy of the plants through orifices that are close together (Bonadio et al., 2015). The chain curtain system includes a set of chains that are arranged on the spray boom, which make the plants incline with the movement of the machine (Moura et al., 2017). The plants are inclined in the direction of the movement of the boom, causing an opening in the canopy and allowing for more deposition of droplets to be achieved in the middle and lower thirds of the crop plants (Witt et al., 2009).
The Dropleg ${ }^{\circledR}$ system consists of a pendant, similar in shape to an inverted cane, at the end of which two spray nozzles are inserted that penetrate the canopy of the crop, directing its sprays from the bottom up with the purpose of reaching different parts inside the canopy of the plants, where it is typically difficulty to deposit agrochemicals. Therefore, this is a system that is applicable for use in several row crops and tends to present greater biological effectiveness against pests and diseases located in parts of the plants that are difficult to access, such as the lower third (Rüegg \& Total, 2013).

The objective of the present study was to evaluate the spray deposition, as well as the coverage of the leaf surface, in the lower, middle, and upper third of soybean plants achieved by different assisted boom sprayer systems.

\section{MATERIAL AND METHODS}

This study was conducted during the 2015/2016 harvest in the experimental field of the University of Passo Fundo, Passo Fundo, RS, Brazil, a site that has an altitude of $687 \mathrm{~m}$ and is located at a latitude of $28^{\circ} 15^{\prime} 41^{\prime \prime} \mathrm{S}$ and a longitude of $52^{\circ} 24^{\prime} 45^{\prime \prime} \mathrm{W}$. The experiment was conducted with soybeans of the cultivar BMX Ativa RR, which presents a determined growth habit and belongs to maturation group 5.6, grows erect, has an early growth cycle, and is susceptible to soybean rust. The soybean crop was planted with a spacing of $0.45 \mathrm{~m}$ between rows and with a density of 30.7 plants $\mathrm{m}^{-2}$.

The deposition and leaf surface coverage of an applied mixture achieved by three different assisted boom sprayer systems were evaluated: the Vortex ${ }^{\circledR}$, Dropleg ${ }^{\circledR}$, and the chain curtain systems; the deposition and coverage achieved by the conventional spray system without the use of assisted mechanisms were also evaluated (Table 1). The deposition and leaf surface coverage were evaluated at the R5.3 stage (Fehr et al., 1971), at which time the plants had a leaf area index of 5.7 and a height of $1.0 \mathrm{~m}$. The plots were $20 \mathrm{~m}$ long and $3.0 \mathrm{~m}$ wide.

TABLE 1. Nozzle type, volume, speed, and pressure of the conventional and assisted boom sprayer systems investigated in this study at Passo Fundo, Brazil, in 2018.

\begin{tabular}{|c|c|c|}
\hline & Treatment & Description \\
\hline 1 & Conventional & $\begin{array}{l}\text { Application volume of } 130 \mathrm{~L} \mathrm{ha}^{-1} \text {, flat fan } \mathrm{LU}^{*} 12002 \text { spray nozzles spaced } 0.50 \mathrm{~m} \text { apart at the top } \\
\text { of the boom, fine droplets, flow rate of } 0.65 \mathrm{~L} \mathrm{~min}^{-1}\end{array}$ \\
\hline 2 & Vortex $^{\circledR}$ & 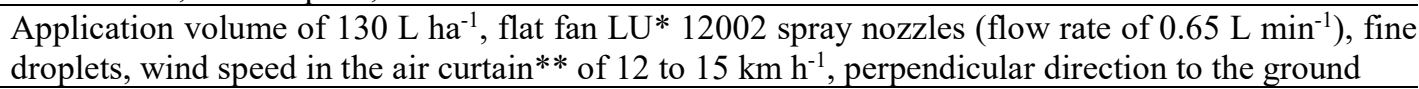 \\
\hline 3 & Dropleg $^{\circledR}$ & $\begin{array}{l}\text { Application volume of } 65 \mathrm{~L} \mathrm{ha}^{-1} \text { at the top and bottom parts, using flat fan LU* } 12001 \text { spray nozzles } \\
\text { (flow rate of, } 0.32 \mathrm{~L} \mathrm{~min}{ }^{-1} \text { ) in the top of the boom, fine droplets combined with two } 8001 \text { nozzles of } \\
\text { empty cone sprays at the end of a flexible rod (flow rate of } 0.32 \mathrm{~L} \mathrm{~min}^{-1} \text { ), fine droplets }\end{array}$ \\
\hline 4 & Chain curtain & $\begin{array}{l}\text { Application volume of } 130 \mathrm{~L} \mathrm{ha}^{-1} \text {, flat fan LU* } 12002 \text { spray nozzles in the top of the boom, fine } \\
\text { droplets (flow rate of } 0.65 \mathrm{~L} \mathrm{~min}^{-1} \text { ), chain curtain placed } 0.4 \mathrm{~m} \text { in front of the boom }\end{array}$ \\
\hline
\end{tabular}

*LU nozzle: plastic nozzle of universal use, manufactured by Lechler, with a movement speed of $6 \mathrm{~km} . \mathrm{h}^{-1}$ and spray pressure of 2.0 bar; ** wind speed measured $0.5 \mathrm{~m}$ from the air outlet. Fine droplets: 106 to $235 \mu \mathrm{m}$ (ANSI/ASAE S572.2 JUL2018). 
The spray mixture was a standard-base mixture that consisted of $130 \mathrm{~L} \mathrm{ha}^{-1}$ of water, a paraffinic mineral oil adjuvant $(42.8 \%)$ at a dose of $0.6 \mathrm{~L} \mathrm{ha}^{-1}$, and a fluorescent tracer (Helios SC $500^{\mathrm{TM}}$, Syngenta) at a dose of $0.1 \% \mathrm{v} / \mathrm{v}$ $\left(65 \mathrm{~mL} \mathrm{ha}^{-1}\right)$. The applications occurred on February 8, 2016, between 18:35 and 19:00, when the average temperature was $25^{\circ} \mathrm{C}$ and there was a $73 \%$ relative humidity and wind speeds between 1.1 and $5.0 \mathrm{~km} \mathrm{~h}^{-1}$. Spraying was done with a Jacto Falcon AM 14 sprayer, with nozzles spaced $0.5 \mathrm{~m}$ apart, spray booms $0.5 \mathrm{~m}$ above the canopy of the plants, and at a movement speed of $6.0 \mathrm{~km} \mathrm{~h}^{-1}$.

For the analysis of deposition, 24 plants were collected at random from each treatment in the central five meters of the plot, where each plant constituted a replicate. The plants were each subdivided into 3 levels (thirds): upper, 0-25 cm from the apex; middle, $26-50 \mathrm{~cm}$ from the apex; and lower, more than $50 \mathrm{~cm}$ from the apex.

The leaves, stems, and fruits of each of the levels were separated. The leaf area was determined using a Licor $^{\circledR}$ 3000 leaf area meter. For the determination of the leaf area, the samples were weighed, and the area was calculated by an area-weight factor previously determined in control plants.

The fluorescent tracer was extracted by washing the plants with diethylene glycol monoethyl ether $(250 \mathrm{~mL}$ per sample) in $5.0 \mathrm{~L}$ plastic bags and shaking them for 30 seconds. A 5.0-mL aliquot was then taken and analyzed with the help of a fluorimeter (Fluorimeter 96 $6^{\mathrm{TM}}$, Novartis) at a wavelength of $365 \mathrm{~nm}$.

The applied standard-base mixture was collected at the beginning and at the end of the spray operation to check the concentration of the tracer. These samples were analyzed and compared with a standard calibration curve. The deposition data obtained from the plant material were expressed in units of $\mathrm{ng} \mathrm{cm}^{-2}$, and the results were calculated as the normalized deposition, $\left(\mathrm{ng} \mathrm{cm}^{-2}\right) /\left(\mathrm{g} \mathrm{ha}^{-1}\right)$, in relation to the initial concentration of the tracer in the standard-base mixture, which allowed comparisons to be made between the different treatments.
To evaluate the spray coverage, 30 leaves were collected from five replicate plants, which were divided into three levels each (upper, middle, and lower), as described above. Both sides of the leaves (abaxial and adaxial) from each portion of the plant were photographed under ultraviolet light because under such light the tracer becomes fluorescent. These images, with a resolution of 7.0 megapixels, were submitted to the FluorSoft ${ }^{\mathrm{TM}}$ image analysis software to determine the area of the leaf on which the presence of the tracer was detected. Thus, the coverage on the abaxial and adaxial sides of the leaves was determined, as well as the total leaf coverage based on the sum of both sides' coverage.

The data were compared among treatments using analysis of variance with the F-test, and means were compared based on their $95 \%$ confidence intervals (95\% CIs).

\section{RESULTS AND DISCUSSION}

Based on the comparisons of means and $95 \%$ confidence intervals $(\mathrm{P}<0.05)$, the deposition of the mixture was significantly influenced by the spray system used (Figure 1). In the upper portion of the plant, the conventional spray system and the Vortex ${ }^{\circledR}$ system behaved similarly, reaching mean $( \pm 95 \% \mathrm{CI})$ tracer deposition levels close to $4.57( \pm 0.35)$ and $4.28( \pm 0.26) \mathrm{ng} \mathrm{cm} / \mathrm{g} \mathrm{ha}^{-1}$, respectively. The chain curtain system resulted in similar deposition in the upper thirds of the plants $(3.72 \pm 0.35 \mathrm{ng}$ $\mathrm{cm}^{-2} / \mathrm{g} \mathrm{ha}^{-1}$ ) to the Vortex ${ }^{\circledR}$ system, and achieved higher deposition than the Dropleg ${ }^{\circledR}$ system by up to $34 \%$ (Figure 1 ).

In the middle third of the plant (Figure 1), the conventional system $\left(1.87 \pm 0.31 \mathrm{ng} \mathrm{cm}^{-2} / \mathrm{g} \mathrm{ha}^{-1}\right)$, the chain system $\left(2.29 \pm 0.49 \mathrm{ng} \mathrm{cm}^{-2} / \mathrm{g} \mathrm{ha}^{-1}\right)$, and the Dropleg ${ }^{\circledR}$ system $\left(2.41 \pm 0.45 \mathrm{ng} \mathrm{cm}^{-2} / \mathrm{g} \mathrm{ha}^{-1}\right)$ reached similar deposition levels; however, the $\operatorname{Vortex}^{\circledR}$ system presented 55\% lower deposition than them $\left(1.07 \pm 0.16 \mathrm{ng} \mathrm{cm} / \mathrm{g} \mathrm{ha}^{-1}\right)$. The greatest contribution of the Dropleg ${ }^{\circledR}$ system to deposition $\left(0.55 \pm 0.15 \mathrm{ng} \mathrm{cm}^{-2} / \mathrm{g} \mathrm{ha}^{-1}\right)$ was observed in the lower third of the plant (Figure 1), where it achieved deposition that was 3.1 times higher than that of the conventional system $(0.18 \pm$ $\left.0.04 \mathrm{ng} \mathrm{cm} / \mathrm{g} \mathrm{ha}^{-1}\right)$ and 1.3 times higher than that of the Vortex ${ }^{\circledR}$ system $\left(0.21 \pm 0.05 \mathrm{ng} \mathrm{cm}{ }^{-2} / \mathrm{g} \mathrm{ha}^{-1}\right)$ and the chain curtain system $\left(0.24 \pm 0.07 \mathrm{ng} \mathrm{cm}^{-2} / \mathrm{g} \mathrm{ha}^{-1}\right)$. 


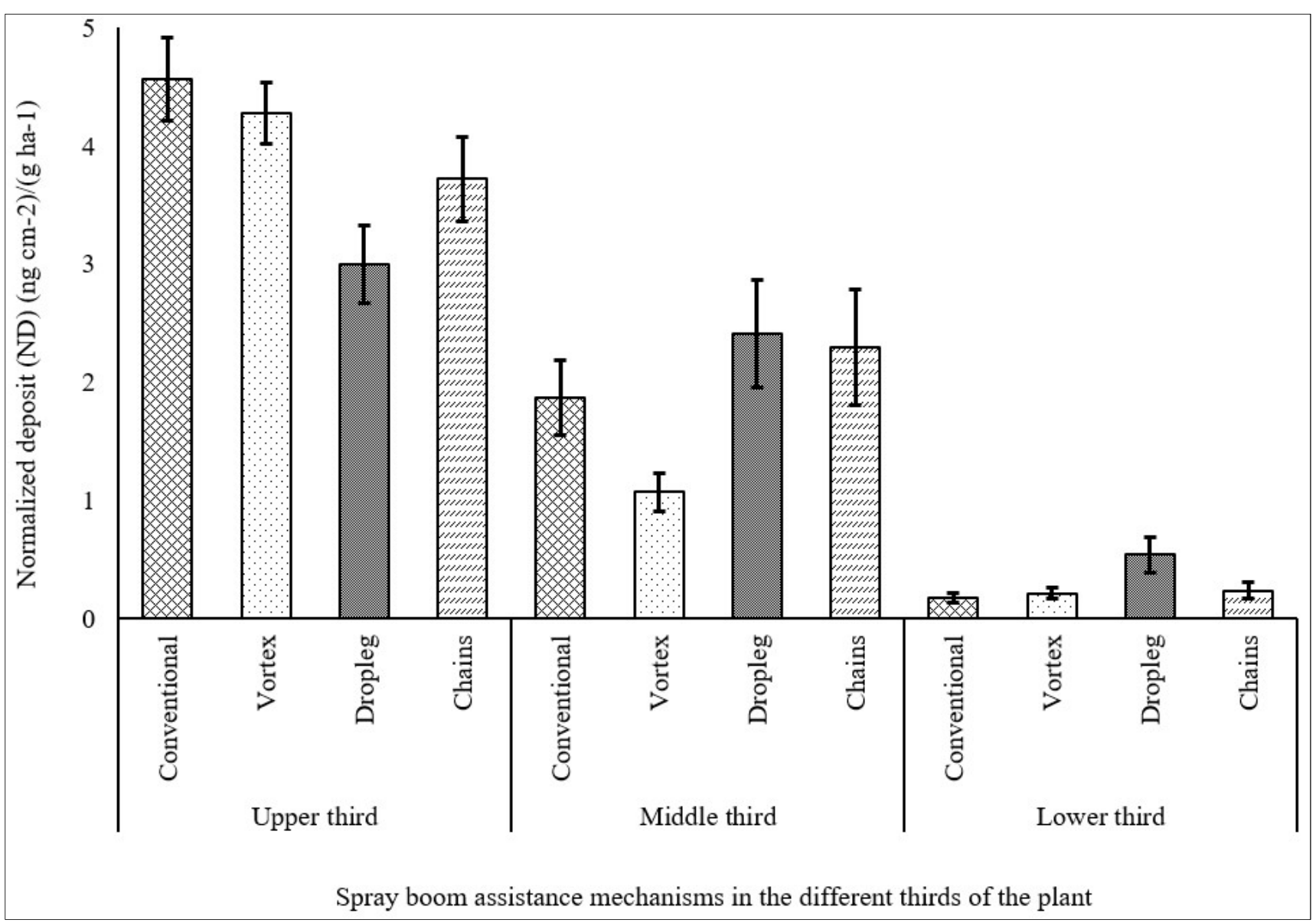

FIGURE 1. Normalized deposition of the Helios 500SC fluorescent tracer $\left(\mathrm{ng} \mathrm{cm}^{-2}\right) /\left(\mathrm{g} \mathrm{ha}^{-1}\right)$ achieved with different spray systems in different parts of soybean plants (upper, middle, and lower thirds) of cultivar BMX Ativa RR in the 2015/2016 season at Passo Fundo, Brazil.

The deposition achieved with the Dropleg ${ }^{\circledR}$ spray system was equivalent in the middle and upper thirds of the plant, and thus this system distributed the applied mixture better than others. The reduced deposition in the upper third with the use of the Dropleg ${ }^{\circledR}$ system may be related to the reduction in the volume of the mixture coming from the upper boom with this system when compared to the other mechanisms.

All of the assisted boom sprayer systems showed variations in deposition, in which deposition was higher in the upper third of the plant and reduced in the middle and lower thirds. The conventional spray system resulted in 2.4 times higher deposition in the upper third of the plant when compared to the middle third, and in the middle third of the plant the deposition was 10.6 times higher than that in the lower third. Further, when analyzing the deposition in the upper third in comparison to the lower third of the plant, a difference of 25.9 times was observed. When using the assisted boom sprayer systems, these variations were minimized, in that using when these methods the deposition was 1.9 times higher in the upper than in the middle third, 5.8 times higher in the middle than in the lower third, and 11.1 times higher in the upper than in the lower third. Among the air-assisted boom sprayer systems, the Dropleg ${ }^{\circledR}$ system presented the lowest variation in deposition among plant parts, with differences only reaching 1.2 times between the upper and middle thirds, 4.4 times between the middle and lower thirds, and 5.5 times between the upper and lower thirds (Figure 1).

The level of coverage of the leaf surface on the adaxial side varied among the assisted boom sprayer systems. In the upper third of the plant (Figure 2), the conventional system $(63.2 \pm 6.8 \%)$ and the Vortex ${ }^{\circledR}$ system $(59.9 \pm 6.0 \%)$ had the highest percent coverages. The Dropleg ${ }^{\circledR}$ system $(35.7 \pm 3.0 \%)$ and the chain curtain system $(40.6 \pm 5.2 \%)$ behaved similarly, and actually had reduced leaf surface coverage by up to $43.5 \%$ compared to the other methods.

In the middle third of the plant (Figure 2), the highest coverage levels of the adaxial surface were obtained with the conventional spray system $(41.4 \pm 6.5 \%)$, followed by the Vortex $^{\circledR}$ system $(25.4 \pm 5.8 \%)$ and the chain curtain system $(23.5 \pm 2.8 \%)$. The use of the Dropleg ${ }^{\circledR}$ system $(16.3$ $\pm 2.7 \%$ ) reduced the percent leaf coverage in the middle third of the plant by up to $60 \%$ compared to the conventional spray system. In the lower third of the plant (Figure 2), the Dropleg ${ }^{\circledR}$ system $(10.0 \pm 4.1 \%)$ and the chain curtain system $(6.4 \pm 1.5 \%)$ had the highest leaf coverage levels, which were up to 3.8 times higher than those achieved by the conventional spray system $(2.8 \pm 0.4 \%)$ and the Vortex ${ }^{\circledR}$ system $(2.4 \pm 0.4 \%)$. 


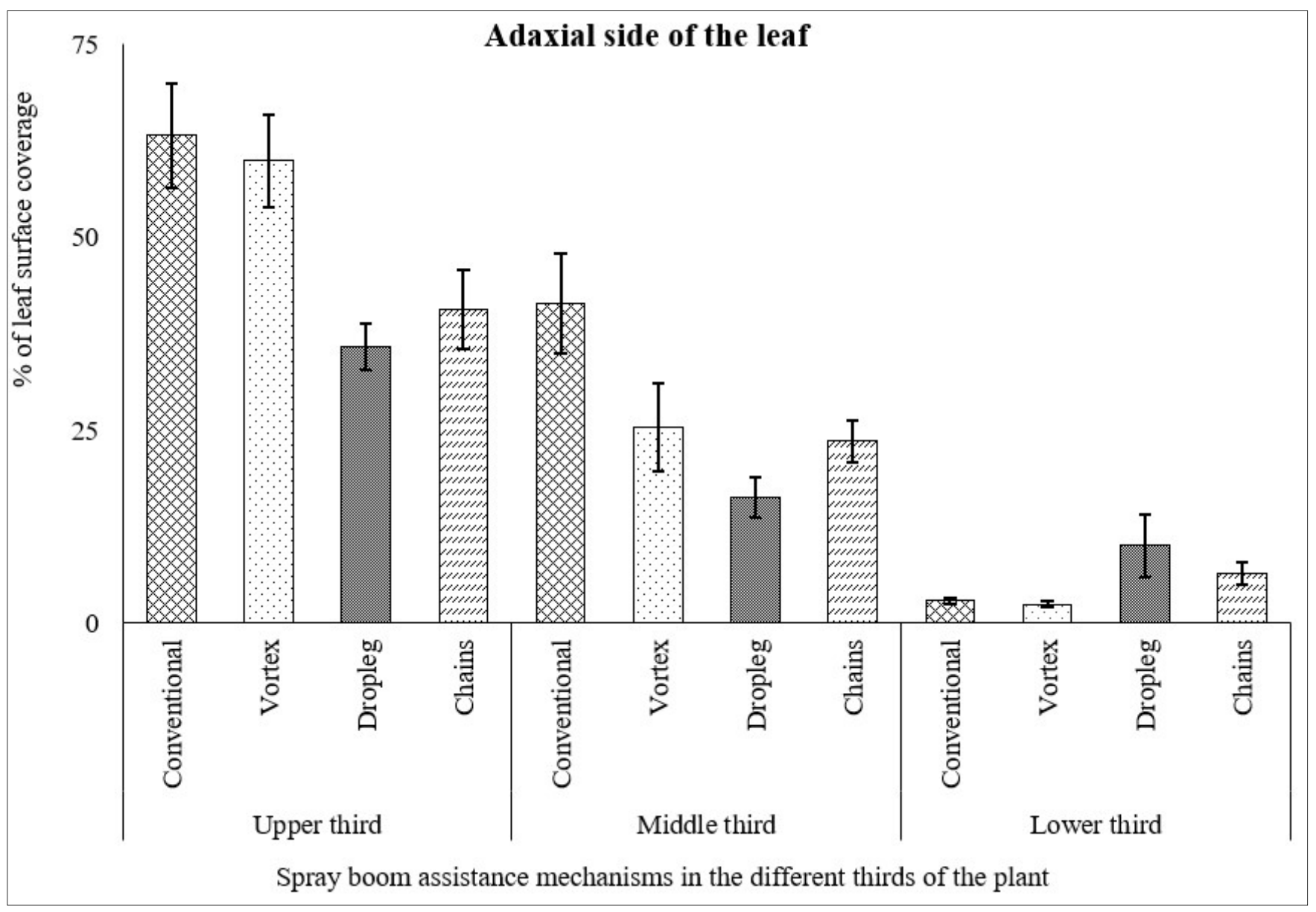

FIGURE 2. Leaf surface coverage (\%) on the adaxial side of the Helios 500SC fluorescent tracer with different spray systems in different parts of soybean plants (upper, middle, and lower thirds) of cultivar BMX Ativa RR in the 2015/2016 season at Passo Fundo, Brazil.

On the abaxial side of the leaves (Figure 3) in the upper third of the plants, the coverage attained using the Dropleg $^{\circledR}$ spray system $(6.5 \pm 0.9 \%)$ was equivalent to that of the conventional spray system $(8.1 \pm 1.7 \%)$, and both of these achieved higher coverage than the chain curtain system (4.2 $\pm 0.9 \%)$. Among the air-assisted boom sprayer systems, the leaf surface coverage achieved by the Vortex ${ }^{\circledR}$ system $(1.6 \pm 0.3 \%)$ was up to $80.2 \%$ of that achieved by the conventional system in the upper third of the plant. In the middle third of the plant (Figure 3), the Dropleg ${ }^{\circledR}$ system $(1.9 \pm 0.2 \%)$ achieved approximately $58 \%$ higher coverage than all the other systems. In the lower third of the plant, the conventional spray system $(1.7 \pm 0.3 \%)$ and the chain curtain system $(1.9 \pm 0.2 \%)$ achieved higher coverage than the $\operatorname{Vortex}^{\circledR}$ system $(1.2 \pm 0.1 \%)$. In addition, in the lower third of the plant, the coverage achieved by the Dropleg ${ }^{\circledR}$ spray system $(1.4 \pm 0.7 \%)$ was equivalent to that of the other systems tested (Figure 3). 


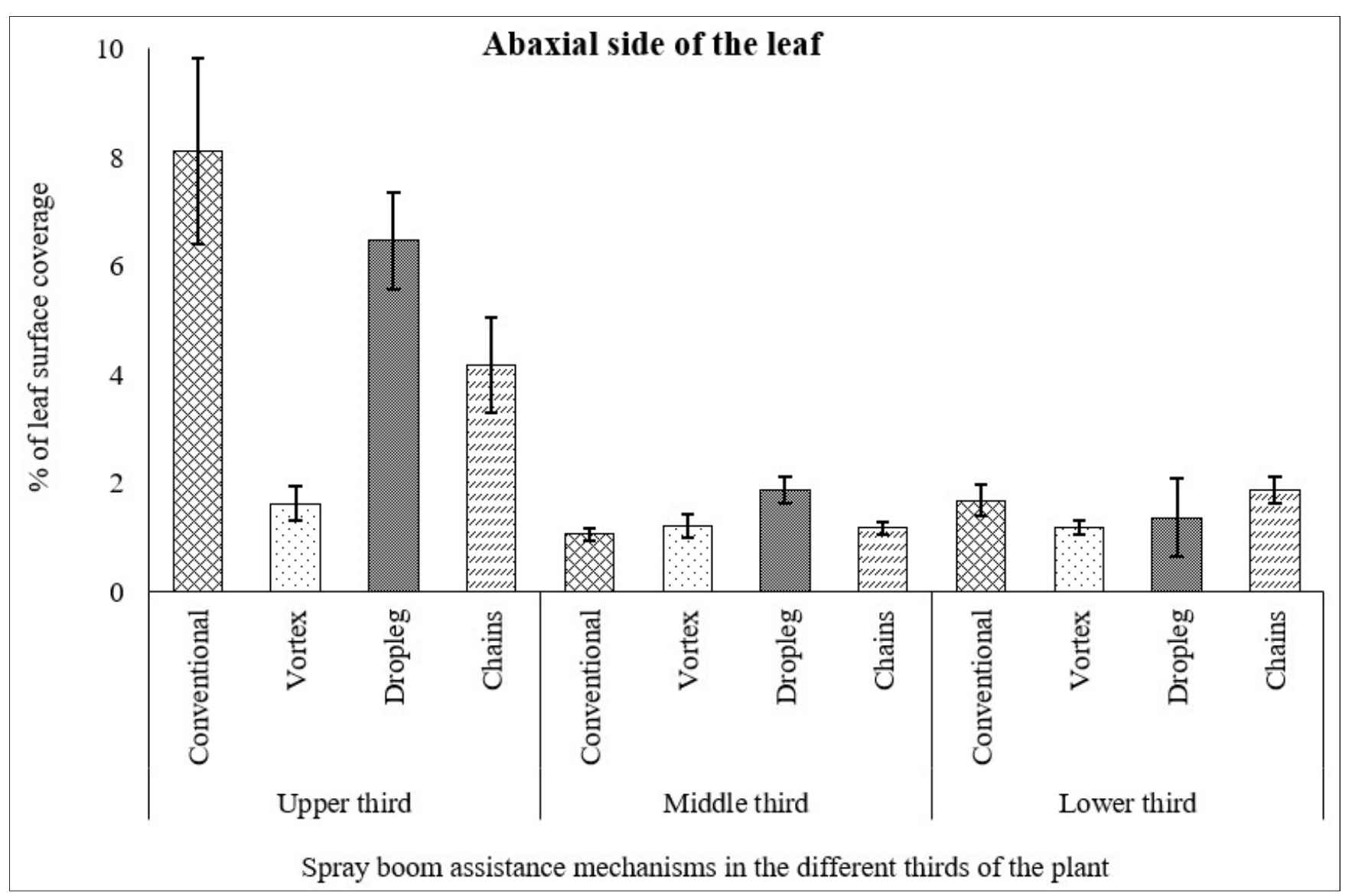

FIGURE 3. Leaf surface coverage (\%) on the abaxial side of the Helios 500SC fluorescent tracer with different spray systems in different parts of soybean plants (upper, middle, and lower thirds) of cultivar BMX Ativa RR in the 2015/2016 season at Passo Fundo, Brazil.

The total coverage of the leaf surface responded significantly to the different tested assisted boom sprayer systems. In the upper third of the plant (Figure 4), the highest percent coverage was obtained with the conventional spray system $(81.5 \pm 9.4 \%)$, followed by the Vortex ${ }^{\circledR}$ system $(70.0 \pm 4.2 \%)$. The total coverage with the Dropleg $^{\circledR}$ system $(46.2 \pm 3.5 \%)$ and the chain curtain system $(41.6 \pm 4.9 \%)$ was up to $49 \%$ lower than that obtained with the other evaluated systems.

In the middle third of the plant (Figure 4), the highest total percent leaf coverage was obtained with the conventional spray system, reaching levels of $43.1 \%$ $( \pm 6.7 \%$ ) that represented $47 \%$ higher coverage than that achieved by the other assisted mechanisms, since the Vortex $^{\circledR}$ system achieved a total leaf coverage of $24.1 \%$ $( \pm 4.3 \%)$, the chain curtain system a coverage of $24.5 \%$ $( \pm 2.7 \%)$, and the Dropleg ${ }^{\circledR}$ system a coverage of $20.3 \%$ $( \pm 2.90 \%)$. The three assisted mechanisms did not significantly differ from one another in this parameter. The total percent leaf coverage obtained with the Dropleg ${ }^{\circledR}$ and the chain curtain systems in the upper third of the plant was equivalent to that obtained with the conventional system in the middle third of the plant, with coverage levels of $42 \%$ (Figure 4).

In the lower third of the plant (Figure 4), the Dropleg $^{\circledR}$ system $(13.2 \pm 5.8 \%)$ and the chain curtain system $(7.6 \pm 1.5 \%)$ achieved higher percent leaf surface coverages than the other systems; however, the coverage obtained with the chain curtain system was similar to that obtained with the conventional spray system $(6.2 \pm 1.1 \%)$. The Vortex $^{\circledR}$ system reached levels of $3.8 \%( \pm 0.4 \%)$ leaf surface coverage, which were lower than those obtained with the other spraying methods evaluated by up to $71 \%$ (in comparison with that of the conventional spray system).

In all four spraying systems evaluated, the percent leaf coverage obtained was reduced from the upper to the lower third of the plant, with variations among treatments of approximately $41 \%$ to $81 \%$ in the upper third, $43 \%$ to $24 \%$ in the middle third, and $13 \%$ to $4 \%$ in the lower third (Figure 4). The conventional spray system presented 1.9 times higher coverage in the upper than in the middle third, 6.9 times higher coverage in the middle than in the lower third, and 13.1 times higher coverage in the upper than in the lower third.

Among the evaluated assisted boom sprayer systems, the Dropleg ${ }^{\circledR}$ system had the lowest variation among plant parts, with this reaching 2.3 times between the upper and middle thirds, 1.5 times between the middle and lower thirds, and 3.5 times between the upper and lower thirds using this system. The chain curtain system had reduced coverage variations compared to those obtained with the conventional system, reaching variations of 1.7 times between the upper and middle thirds, 3.2 times between the middle and lower thirds, and 5.5 times between the upper and lower thirds (Figure 4). Among the mechanisms evaluated, the Vortex ${ }^{\circledR}$ system had the highest levels of variation, with variations of 2.9 times between the upper and middle thirds, 6.3 times between the middle and lower thirds, and 18.4 times between the upper and lower thirds (Figure 4). 


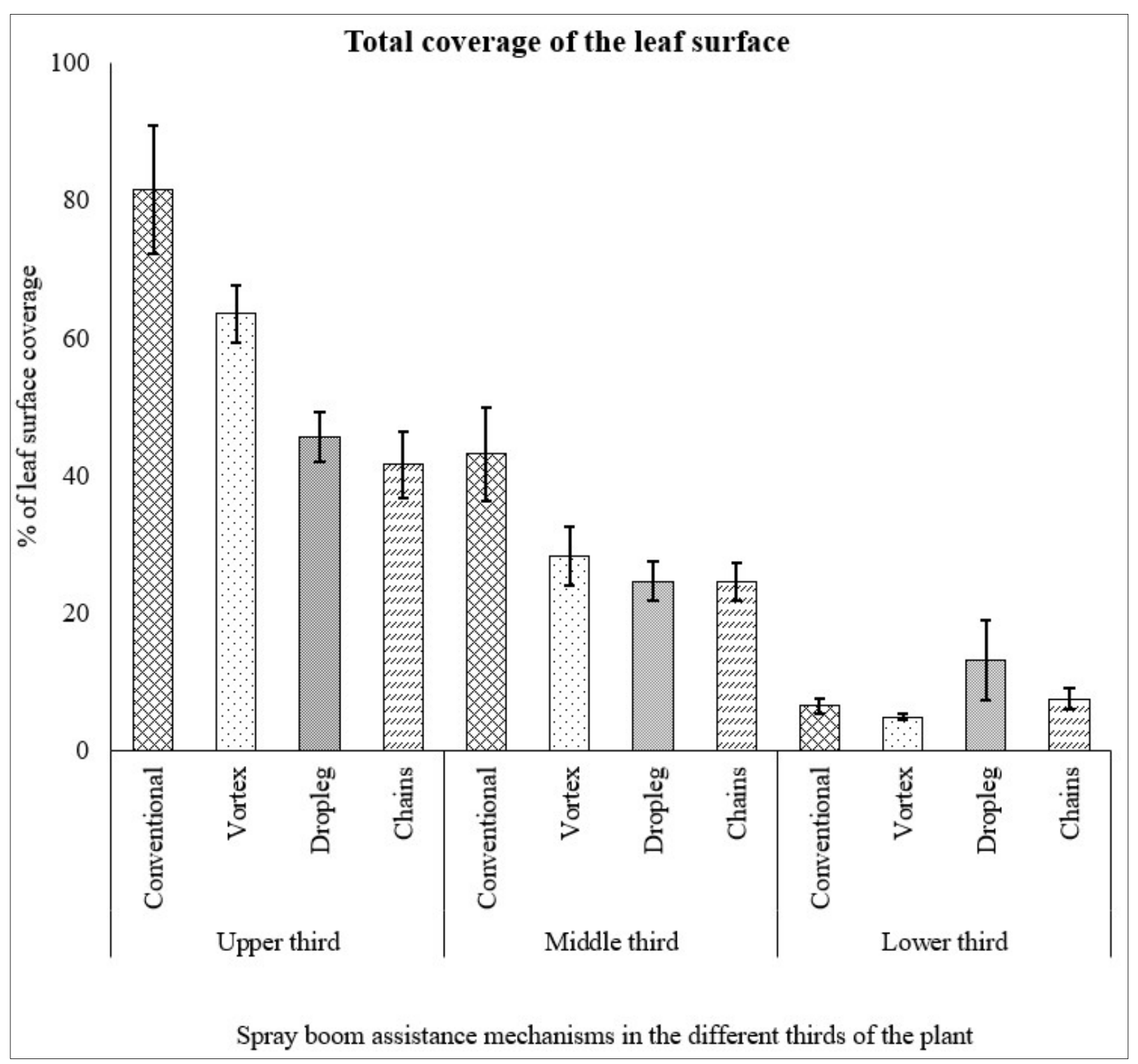

FIGURE 4. Total coverage of the leaf surface (\%) of the Helios 500SC fluorescent tracer with different spray systems in different parts of soybean plants (upper, middle, and lower thirds) of cultivar BMX Ativa RR in the 2015/2016 season at Passo Fundo, Brazil.

Assisted boom sprayer systems have the potential to increase the deposition and leaf surface coverage of sprayapplied chemicals throughout the plant, and may be especially useful in minimizing the variations among the different thirds, thus achieving greater homogeneity in the distribution of applied agrochemicals. Thus, it is possible to use these to maximize pest and disease control levels, as well as to minimize problems caused by the excess accumulation of the active ingredient in the spray at only one part of the plant, which can lead to phytotoxicity.

The Vortex ${ }^{\circledR}$ system is an important tool that permits adjustments in the control of spray drift (Bauer \& Raetano, 2000); however, there is no consistency in its performance. In previous studies, the Vortex ${ }^{\circledR}$ system was shown to increase the deposition of a spray mixture inside the canopy of a soybean crop (Baesso et al., 2014), as well as to improve the control of soybean rust, increasing the yield and the mass per thousand soybean grains (Christovam et al., 2010; Prado et al., 2010). On the other hand, cases have been reported wherein such assisted methods did not influence spray deposition levels (Aguiar Júnior et al., 2011), and in some studies, air-assisted boom spraying had no effect on the performance of agrochemicals, in that it did not potentiate nor did it compromise the control levels of phytopathogenic fungi (Oliveira et al., 2016).

The variation in the results obtained with the Vortex ${ }^{\circledR}$ system may be related to plant-associated factors, especially the opening of the canopy at the time of the application, which can be influenced by the arrangement of the plants (Holtz et al., 2014), characteristics of the cultivar (Debortoli et al., 2012; Tormen et al., 2012), and the time of day at which spraying occurs since the angles of soybean leaves relative to the ground vary throughout the day (Graziano et al., 2017; Moura et al., 2017). Therefore, when the canopy is more open, there may be no influence of the air curtain, which is mainly useful only with a closed canopy at the more advanced stages of crop development. In addition, the performance of the $\operatorname{Vortex}^{\circledR}$ system is influenced by the features of the application technology used, such as the air curtain speed (Aguiar Júnior et al., 2011), uniform distribution of air along the boom, angle of the spray nozzles, airflow in relation to the spray direction (Christovam et al., 2010), and the size spectrum of the droplets applied (Matthews et al., 2014). 
The Dropleg ${ }^{\circledR}$ system is built on the principle of optimizing deposition in places that are hard to reach, such as the lower third of the plant, since the system operates inside of the canopy. In addition, it allows for greater control of the spray drift by the wind, which permits the use of smaller droplets (Roten et al., 2013; Rüegg \& Total, 2013). The use of the Dropleg ${ }^{\circledR}$ system had negative impacts on the deposition and leaf coverage in the upper third of the crop in the present study. Application of $65 \mathrm{~L} \mathrm{ha}^{-1}$ from the top of the boom and $65 \mathrm{~L} \mathrm{ha}^{-1}$ from the flexible rod contributed to reductions in the analyzed variables, especially the leaf coverage, which were related to the volume of the mixture (Roehrig et al., 2018). Thus, it is necessary to vary the ratio between the amounts sprayed at different levels with the Dropleg ${ }^{\circledR}$ system in relation to those of the conventional spray-boom system.

In previous studies conducted on bean crops in France and Switzerland, the use of the Dropleg ${ }^{\circledR}$ system improved the biological efficacy of fungicides applied against Sclerotinia sp., which increased from $40 \%$ with a conventional spray system to $80 \%$ with the use of the Dropleg ${ }^{\circledR}$ system (Rüegg \& Total, 2013). Some studies have also been carried out with soybean crops, in which it was observed that productivity, the coverage of the lower leaves, and the density of droplets deposited on the plants were not changed by the use of the Dropleg ${ }^{\circledR}$ system compared to the conventional spray system (Alves \& Cunha, 2011; Cunha et al., 2014).

In the present study, the variations in deposition and leaf coverage with the Dropleg ${ }^{\circledR}$ system may have been associated with the adjustment of the system for use in the soybean canopy. The flexible rod used has a length of 0.9 $\mathrm{m}$, so with the spray boom operating $0.5 \mathrm{~m}$ above the canopy of the plants, the penetration of the rod was approximately $0.4 \mathrm{~m}$ inside the canopy, and thus considering that the plants had a height of $1.0 \mathrm{~m}$ the spray did not reach the entire lower third of the plants. This system could be improved with the use of a larger rod. A crop of plants with a height of $1.0 \mathrm{~m}$ would require a rod of $1.4 \mathrm{~m}$ to $1.5 \mathrm{~m}$ in length. In this case, it would also be necessary to use nozzles in the intermediate parts of the rod, not only at the lower end. Whether the maintenance of the total volume of the mixture at both spray nozzles without dividing it between the thirds would improve the performance of this system should also be explored, since the two-way division of the spray volume caused less coverage and less deposition to be achieved on the upper parts of the plants in the present study.

When working with the chain curtain system, Moura et al. (2017) observed that the greatest benefits were obtained if the spray applications were performed in the early morning, as this is when there is dew present and when the upper thirds of the plants assume a horizontal position in relation to the soil, making it more difficult for the spray droplets to be deposited in conventional systems. Thus, interactions between the application system and its application time can occur, as the results of the application of fungicides for the management of soybean rust at 12:00 and 15:00 did not differ depending on whether or not airassisted boom sprayer systems were used in this study. In addition, the use of the chain curtain improved the deposition of spray droplets in the lower thirds of the plants regardless of the time of application (Moura et al., 2017).
The chain curtain system can optimize the deposition of droplets on the lower part of the plant, resulting in greater control of soybean rust, and thus optimizing the grain yield. However, it is necessary to take into account the application time and the architecture of the cultivar, since the best results are obtained in cultivars with a high leaf area index, especially if applications are performed in the early morning (Moura et al., 2017).

Besides using assisted boom sprayer systems, the deposition and coverage of the leaf surface by sprayed chemicals can be maximized by adjusting other factors, such as: the spectrum of the droplets (Silva et al., 2014, Weber et al., 2017; França et al., 2018), spray pressure (Cunha et al., 2016), spray nozzle type (Cunha et al., 2014; Madureira et al., 2015; Cunha et al., 2016, Durão \& Boller, 2017), adding adjuvants to the spray (Cunha et al., 2014; Madureira et al., 2015; Oliveira et al., 2016), and changing the volume of the mixture (Cunha et al., 2014; Prado et al., 2015; Weber et al., 2017; Roehrig et al, 2018).

The time of day at which the application occurs can influence the deposition as well as the percent coverage of the leaf surface achieved due to the movement of the leaves (heliotropism). Thus, a strategy to maximize the effectiveness of agrochemicals should include the means to improve their distribution throughout the plant, especially at times close to 13:00. It should also be noted that the application schedule interacts with the spectrum of the droplets and the volume of the mixture, in addition to the use of air-assisted boom sprayer systems (Graziano et al., 2017; Moura et al., 2017).

Because of the reduced sensitivity of the plant pathogen Phakopsora pachyrhizi to triazole, strobilurin, and carboxamide fungicides, multisite fungicides (mancozeb, chlorothalonil, and copper sulfate, among others) have begun to be used in soybean cultivation to manage soybean rust. This is done with the goal of increasing disease control efficiency, as well as minimizing the risks of pathogens developing resistance (Juliatti et al., 2017; Godoy et al., 2016, Silva et al., 2015).

Multisite fungicides form a superficial protective barrier against infection, which is therefore non-penetrating and immobile. When applied to the aerial organs of plants, these fungicides are not absorbed, so they do not move and remain on the surface of the plant where they were deposited (Reis et al., 2010). Given these characteristics, it is very important to search for strategies to maximize the deposition of fungicides, as well as their coverage of the leaf surface throughout the plant, to optimize disease control and thus reduce losses and damages to crops caused by diseases. Therefore, the air-assisted boom sprayer systems examined in this study have the potential to be used, with some adjustments, to achieve these goals. They may also be used in the essential adjustment of fungicide application technologies, taking into account all the aspects that make it possible to distribute such protective agrochemicals throughout the plant. 


\section{CONCLUSIONS}

The use of assisted boom sprayer systems improved the distribution of the applied mixture throughout the plant by reducing the variations among the upper, middle, and lower thirds of plants in both the levels of deposition and leaf surface coverage. The Dropleg ${ }^{\circledR}$ system increased the deposition and leaf coverage in the lower third of the plant the most, and thus provided a better distribution of the applied mixture than the other methods tested.

\section{REFERENCES}

Aguiar Júnior HO, Raetano CG, Prado EP, Dal Pogetto MHFA, Christovam RS, Gimenes RS (2011) Adjuvantes e assistência de ar em pulverizador de barras sobre a deposição da calda e controle de Phakopsora pachyrhizi (Sydow \& Sydow). Summa Phytopathologica 37(3):103-109.

Alves GS; Cunha JPAR (2011) Deposição de calda em diferentes posições da planta e produtividade da cultura da soja (Glycine max (L.) Merril) com o uso de barra auxiliar de pulverização. Enciclopédia Biosfera 7(12):1-8.

ASABE - American Society of Agricultural and Biological Engineers (2018) ASAE S572 Spray Nozzle classification by Droplet Spectra. $2^{\text {sd }}$ ed. ASABE.

Baesso MM, Rodrigues Junior FA, Magno Junior RG, Teixeira MM, Modolo AJ (2014) Population and spectrum of droplets produced during electrostatic spraying and hydraulic spraying using air assistance. Engenharia na Agricultura 22(5):408-412.

Bauer FC, Raetano CG (2000) Assistência de ar na deposição e perdas de produtos fitossanitários em pulverizações na cultura da soja. Scientia Agricola 57(2):271-276.

Bonadio JAB, Arcuri Neto J, Costa NV, Ramella JRP (2015) Tecnologia de aplicação de defensivos agrícolas: inovações. In: Kuhn OJ et al. (orgs) Ciências agrárias: tecnologias e perspectivas. Universidade Estadual do Oeste do Paraná, 360 p.

Christovam RS, Raetano, CG, Aguiar Junior HO, Dal-Pogetto MHFA, Prado EP, Gimenes Junior M, Kunz VL (2010) Assistência de ar em barra de pulverização no controle da ferrugem asiática da soja. Bragantia 69(1):231-238.

Cunha JPRC, Marques RS, Alves GS (2016) Deposição da calda na cultura da soja em função de diferentes pressões de trabalho e pontas de pulverização. Ceres 63(6):761-768.

Cunha JPAR, Juliatti FC, Reis EF (2014) Tecnologia de aplicação de fungicidas no controle da ferrugem asiática da soja: resultados de oito anos de estudos em Minas Gerais e Goiás. Bioscience Journal 30(4):950-957.

Debortoli MP, Tormen NR, Balardin RS, Fávera DD, Stefanello MT, Pinto FF, Uebel JD (2012) Efeito dos espectros de gota associados a diferentes arquiteturas de cultivares de soja no controle da ferrugem. Pesquisa Agropecuária Brasileira 47(7):920-927.

Durão C, Boller W (2017) Spray nozzles performance in fungicides applications for asian soybean rust control. Engenharia Agrícola 37(4):709-716.
Fehr WR, Caviness CE, Burmood DT, Pennington JS (1971) Stage of development descriptions for soybeans, Glycine max (L.) Merrill. Crop Science 11:929-931.

França JAL, Cunha JPAR, Antuniassi UR (2018) Spectrum and velocity of droplets of spray nozzles with and without air induction. Engenharia Agrícola 38(2):232-237.

Godoy CV, Seixas CD, Soares RM, Guimarães FCM, Meyer MC, Costamilan LM (2016) Asian soybean rust in Brazil: past, present, and future. Pesquisa Agropecuária Brasileira 51(5):407-421.

Graziano CEPL, Alves KA, Gandolfo MA, Dario G, Oliveira RB (2017) Spraying quality of crop protection products using two droplet spectra in three periods of the day. Engenharia Agrícola 37(6):1183-1189.

Holtz V, Couto RF, Oliveira DG, Reis EF (2014) Deposição de calda de pulverização e produtividade da soja cultivada em diferentes arranjos espaciais. Ciência Rural 44(8):1371-1376.

Juliatti FC, Polloni LC, Morais TP, Zacarias NRS, Silva EA, Juliatti BCM (2017) Sensitivity of Phakopsora pachyrhizi populations to dithiocarbamate, chloronitrile, triazole, strobilurin, and carboxamide fungicides. Bioscience Journal 33(4):933-943.

Madureira RP, Raetano CG, Cavalieri JD (2015) Interação pontas-adjuvantes na estimativa do risco potencial de deriva de pulverizações. Engenharia Agrícola e Ambiental 19(2):180-185.

Matthews GA, Bateman R, Miller P (2014) Pesticide application methods. Wiley - Blackwell, 4ed. 536p

Moura B, Deuner CC, Visintin G, Boller W (2017) Use of a canopy opener in fungicide applications to improve asian soybean rust control. Transactions of the ASABE 60(6):1819-1825.

Müller M, Rakocevic M, Caverzan A, Boller W, Chavarria G (2018) Architectural Characteristics and Heliotropism May Improve Spray Droplet Deposition in the Middle and Low Canopy Layers in Soybean. Crop Science 58(5):2029-2041.

Oliveira GM, Canteri MG, Saab OJGA (2016) Metaanalysis of scientific studies related to pesticide application techniques-air assistance and adjuvant addition. Ciência Rural 46(12):2122-2128.

Prado EP, Raetano CG, Aguiar Júnior HO, Dal Pogetto MHFA, Christovam RS, Gimenes MJ, Araújo D (2010) Velocidade do ar em barra de pulverização na deposição da calda fungicida, severidade da ferrugem asiática e produtividade da soja. Summa Phytopathologica 36(1):45-50.

Prado EP, Raetano CG, Dal Pogetto MHF, Costa SAI, Christovam RS (2015) Taxa de aplicação e uso de surfactante siliconado na deposição da pulverização e controle da ferrugem da soja. Engenharia Agrícola 35(3):514-527

Reis EM, Reis AC, Carmona MA (2010) Manual de Fungicidas: guia para o controle químico de doenças das plantas. Passo Fundo, Universidade de Passo Fundo, 226 p. 6 ed. 226 p. 
Roehrig R, Boller W, Forcelini CA, Chechi A (2018) Use of surfactant with different volumes of fungicide application in soybean culture. Engenharia agrícola 38(4):577-589.

Roten RL, Hewitt AJ, Ledebuhr M, Thistle H, Connell RJ, Wolf TM, Sankar S, Woodward SJR (2013) Evaluation of spray deposition in potatoes using various spray delivery systems. New Zealand Plant Protection 66:317-323.

Rüegg J, Total R (2013) Dropleg-Application Technique for better targeted sprays in row crops Introduction and Hints for Growers and Advisers. Waedenswill, Agroscope, 27p.

Silva LHCP, Campos HD, Silva JRC, Reis EM (2015) Controle da ferrugem asiática da soja com mancozebe um fungicida multissítio. Summa Phytopathologica 41(1):64-67.

Silva BM, Ruas RAA, Sichocki D, Dezordi LR, Caixeta LF (2014) Deposição da calda de pulverização aplicada com pontas de jato plano em diferentes partes da planta de soja (Glycine max) e milho (Zea mays). Engenharia na agricultura 22(1):17-24.
Tormen NR, Silva FDL, Debortoli MP, Uebel JD, Fávera DD, Balardin RS (2012) Deposição de gotas no dossel e controle químico de Phakopsora pachyrhizi na soja. Engenharia Agrícola e Ambiental 16(7):802-808.

Weber NC, Santos EM, Russini A, Silva FF (2017) Deposição de calda ao longo do dossel na cultura da soja utilizando pulverizador equipado com controlador de fluxo. Engenharia na Agricultura 25(5):459-468.

Witt JS, Boller W, Araújo EC, Rodighiero CP, Maldaner H, Ceccon R (2009) Desenvolvimento de mecanismo para auxiliar a deposição de gotas no interior do dossel da cultura da soja com pulverizador de barras. In: 37 Reunião de Pesquisa de Soja da Região Sul. Porto Alegre, UFRGS, Atas e Reusmos...

Wolf RE, Daggupati NP (2009) Nozzle type effect on soybean canopy penetration. Applied Engineering in Agriculture 25(2):23-30. 